\title{
Sobre um amigo
}

Conheci o professor João Ernesto Castro, meu amigo e compadre, em 1977, quando ele veio fazer seu mestrado na Engenharia de Produção da UFSC, ele que era formado em Engenharia Metalúrgica pela UFGRS. Incrivelmente nos identificamos no primeiro encontro, ficamos amigos e, dede lá nossas famílias foram crescendo e ficaram muito amigas também. O Castro sempre foi um abnegado pelo ensino. Teve a grande sorte de ter sido pai e professor (no sentido restrito da palavra) de seus próprios filhos, que cursaram Engenharia de Produção. Mas ele também foi professor e, por que não dizer, pai de todos os alunos que passaram pela Engenharia de Produção. Dedicava-se aos alunos! Foi também amigo e professor dos professores. Eu, que dividi várias disciplinas com ele, me deleitava ouvindo a sua parte, sempre relacionando a matéria com fatos históricos. Lecionava Gestão de Projetos contando pormenores da construção das pirâmides que só os historiadores sabiam. Lecionava Matemática Financeira falando de tratados da era romana que justificavam os juros compostos. Tudo com muito senso de humor. Foi um grande professor! Completo. Além disso, teve vida comunitária intensa, participando de conselhos e associações de classe, especialmente as de Engenharia de Produção. Aliás, a criação dos cursos de graduação em Engenharia de Produção da UFSC conferem a ele status nacional. Sempre será lembrado como um dos grandes da Engenharia de Produção nacional. Por fim, vale lembrar que lá na década de 90 perguntei a ele porque, sendo tão amigos ele nunca tinha me convidado para entrar no Rotary. Realmente eu não estava solicitando para entrar, queria apenas saber o que era Rotary. Ele não me respondeu. Alguns dias depois me ligou dizendo que minha posse no Rotary seria dia 06 de novembro (de 1996) e ele (então secretário) junto com o Lauro Salvador (então presidente), agilizaram o processo para aproveitar a reunião com a presença do Governador. Pegou-me de jeito. Estava tão por fora que pensei se tratar do Governador do Estado. Quis argumentar qualquer coisa mas ele me interrompeu bruscamente: não me faça essa desfeita! E me entregou material de instrução para ler. Tinha razão! Hoje somos vários afilhados seus aqui no clube e que devem ter boas histórias para contar sobre um companheiro honesto, ético, amigo, pai, professor que tinha a prova quádrupla pendurada em sua sala de trabalho para que todos a vissem. Não é preciso dizer mais nada!

Nelson Casarotto Filho (amigo, colega e companheiro no Rotary Club de Florianópolis) 